\title{
In the Matter of
}

\section{NAT TURNER}




\title{
Meherrin Road, south of Cross Keys Road, north of Boykins, Virginia
}

\section{SIC SEMPER TYRANNIS}

\author{
State Historical Marker U 122
}

\section{Nat Turner's Insurrection}

On the night of 21-22 August 1831, Nat Turner, a slave preacher, began an insurrection some seven miles west with a band that grew to about 70 . They moved northeast toward the Southampton County seat, Jerusalem (now Courtland), killing about 60 whites. After two days militiamen and armed civilians quelled the revolt. Turner was captured on 30 October, tried and convicted, and hanged on 11 November: some 30 blacks were hanged or expelled from Virginia. In response to the revolt, the General Assembly passed harsher slave laws and censored abolitionists. 


\section{In the Matter of NAT}

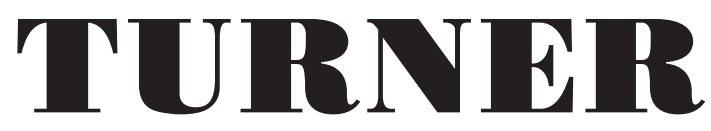

A Speculative History

\section{CHRISTOPHER TOMLINS}


Copyright (C) 2020 by Princeton University Press

Requests for permission to reproduce material from this work should be sent to permissions@press.princeton.edu

Published by Princeton University Press

41 William Street, Princeton, New Jersey 08540

6 Oxford Street, Woodstock, Oxfordshire ox20 1TR

press.princeton.edu

All Rights Reserved

Library of Congress Control Number: 2019953980

ISBN 978-0-691-19866-8

ISBN (e-book) 978-0-691-19987-0

British Library Cataloging-in-Publication Data is available

Editorial: Eric Crahan, Pamela Weidman, and Thalia Leaf

Production Editorial: Nathan Carr

Text Design: Pamela L. Schnitter

Jacket/Cover Design: Pamela L. Schnitter

Jacket images: (Top) Map of Elizabeth City County, VA, from actual surveys by E.A. Semple, Wm. Ivy, and C. Hubbard, 1892. Library of Congress (Right) Marble head of Memnon, student of Herodes Atticus, ca. 170 AD. Photo: bpk Bildagentur / Altes Museum, Belin / Juergen Liepe / Art Resource, NY (Bottom) Green Hill Plantation, slave quarters, State Route 728, Long Island, Campbell County, VA.

Production: Danielle Amatucci

Publicity: Jodi Price and Kate Farquhar-Thomson

This book has been composed in Baskerville 120 Pro and Bodoni Std

Printed on acid-free paper. $\infty$

Printed in the United States of America

10988765543221 
FOR ANN, WITH LOVE 
One might ... speak of an unforgettable life or moment even if all men had forgotten it. If the nature of such a life or moment required that it be unforgotten, that predicate would not imply a falsehood but merely a claim not fulfilled by men, and probably also a reference to a realm in which it is fulfilled:

God's remembrance.

—WALTER BENJAMIN（1923）

And we are witnesses of all things which he did ... whom they slew and hanged on a tree.

-ACTS 10:39 